\title{
Pengembangan Variasi Latihan Pada Atlet Lempar Cakram Pemula
}

\section{Development of Exercise Variations in Beginner Discus Throwing Athletes}

\author{
Hery Julyanto Halawa ${ }^{1}$, Rahman Situmeang ${ }^{2}$ \\ ${ }^{12}$ Fakultas Ilmu Keolahragaan, Universitas Negeri Medan
}

Email: heryjulyanto23@gmail.com

\begin{abstract}
ABSTRAK
This study aims to develop training variations in beginner discus throwers. The population in this study were all beginner discus throwers Simamora Nabolak Atletik Club, SMA Private HKBP 2 Tarutung Atletik Club, SANMAR Athletic Club, and Siborongborong Atletik Club Generation. The form of variation that was made was first validated by 2 (two) experts in the field of sports, namely 1 (one) athletic trainer who has a regional license, and 1 (one) sports academic from the University who has a master's degree in sports education where the percentage of validity is $71 \%$ - 91\%. Small group test involving 15 athletes from Simamora Nabolak Atletik Club, Private High School HKBP 2 Tarutung Atletik Club, SANMAR Atletik Club showed that the percentage of validity was between $67 \%-97 \%$. The results of the large group test involving 21 athletes from Simamora Nabolak Atletik Club, SMA Private HKBP 2 Tarutung Atletik Club, SANMAR Atletik Club, and Siborongborong Atletik Club Generation showed that the percentage validity was between $73 \%-92 \%$. It was concluded from the 20 variations of training for beginner discus throwing athletes to improve the ability of beginner discus throwing athletes because it contains elements of physical and technical training that are in accordance with the training criteria for beginner athletes so that they can be a reference for coaches.
\end{abstract}

\section{Kata Kunci: Variasi Latihan, Lempar Cakram, Pemula}

\begin{abstract}
This study aims to develop training variations in beginner discus throwers. The population in this study were all beginner discus throwers Simamora Nabolak Atletik Club, SMA Private HKBP 2 Tarutung Atletik Club, SANMAR Athletic Club, and Siborongborong Atletik Club Generation. The form of variation that was made was first validated by 2 (two) experts in the field of sports, namely 1 (one) athletic trainer who has a regional license, and 1 (one) sports academic from the University who has a master's degree in sports education where the percentage of validity is $71 \%-91 \%$. Small group test involving 15 athletes from Simamora Nabolak Atletik Club, Private High School HKBP 2 Tarutung Atletik Club, SANMAR Atletik Club showed that the percentage of validity was between $67 \%-97 \%$. The results of the large group test involving 21 athletes from Simamora Nabolak Atletik Club, SMA Private HKBP 2 Tarutung Atletik Club, SANMAR Atletik Club, and Siborongborong Atletik Club Generation showed that the percentage validity was between $73 \%-92 \%$. It was concluded from the 20 variations of training for beginner discus throwing athletes to improve the ability of beginner discus throwing athletes because it contains elements of physical and technical training that are in accordance with the training criteria for beginner athletes so that they can be a reference for coaches.
\end{abstract}

Keywords: Exercise Variation, Throw Discus, Beginners 


\section{PENDAHULUAN}

Dalam kehidupan manusia sekarang ini, tidak dapat lepas dari yang namanya olahraga dan bahkan menjadi populer untuk menjadi pembahasan masyarakat lokal maupun luar (Alfiansyah et al., 2020). Kegiatan olahraga tidak dapat terpisahkan dari semua aspek kehidupan manusia, yaitu kesehatan jasmani dan rohani bagi manusia merupakan suatu hal yang penting dalam menghadapi tantangan hidup sepanjang hidupnya. Bagaimana pula suatu bangsa akan membangun bangsanya kalau masyarakatnya tidak sehat.

Kemajuan ilmu pengetahuan dan teknologi dewasa ini membawa dampak dalam berbagi kehidupan termasuk olahraga (Nugroho et al., 2021). Khususnya cabang olahraga atletik mengalami kemajuan yang sangat pesat,sehingga perkembangan ini mendorong para pembina dan pelatih olahraga bekerja lebih efektif dalam melakukan tehnik-tehnik melatih atau membina atlet yang berbakat.

Cabang olahraga atletik merupakan cabang olahraga yang sangat populer dan paling tua diantara cabang olahraga lainnya. hal ini dikarenakan gerakan- gerakan dalam atletik merupakan gerakan yang biasa dilakukan manusia dalam kehidupan sehari- hari. Bangsa Belanda menyebut atletik dengan sebutan "Atletik is a moerder der sporten" yang artinya adalah induk dari semua cabang olahraga. Karena semua gerakan dalam atletik merupakan gerak dasar seperti jalan, lari, lompat, dan lempar. Hingga sekarang atletik dengan pesat berkembang hampir diseluruh dunia termasuk di Indonesia.

Lempar cakram merupakan salah satu nomor atletik dengan keterampilan gerakan yang sangat kompleks dengan seluruh anggota badan sangat berperan. Untuk bisa berprestasi dalam olahraga ini diperlukan keuletan, ketangkasan, ketekunan berlatih, kecerdasan berpikir dan penguasaan tehnik yang baik dan benar. Disamping itu, peranan pelatih sangatlah penting dalam ketercapaian prestasi seorang atlet.

Selain menyusun program latihan, pelatih juga harus memiliki pengalamanpengalaman yang tinggi disertai dengan pengetahuan dan ide-ide baru (Sinulingga et al., 2020) untuk membuat suatu latihan lebih efisien, efektif, dan sistematis.

Peranan pelatih dalam proses latihan sangat berpengaruh terhadap kemauan dan semangat atlet dalam berlatih, dimana seorang pelatih harus mampu menciptakan variasi-variasi latihan untuk mengurangi rasa 
jenuh dan bosan padasetiap sesi latihan. "Training adalah suatu proses yang amat kompleks yang melibatkan variabel-variabel internal dan eksternal, antara lain motivasi dan ambisi atlet, kuantitas dan kualitas latihan, volume dan intensitas latihan, pengalaman-pengalaman bertanding. Pada nomor lempar cakram sangat dibutuhkan komponen-komponen kondisi fisik yang baik, seperti kekuatan, kelentukan, power, keseimbangan dan koordinasi. Kemampuan kondisi fisik diatas merupakan unsur yang sangat utuh dan tidak dapat dipisahkan dari segi pemeliharaan maupun peningkatannya.

Dalam olahraga prestasi pada nomor lempar cakram, tentunya harus memiliki tehnik yang sempurna dan didukung dengan fisik yang prima (Fatmala et al., 2018). Berbagai bentuk latihan yang dilakukan untuk meningkatkan tehnik dan fisik telah diberikan oleh para pelatih terhadap atlet, tetapi terkadang dengan bentuk latihan yang monoton atau yang sudah sering dilakukan secara berulang-ulang dalam setiap sesi latihan, sering sekali atlet merasa jenuh dan bosan dalam mengikuti sesi latihan.

Simamora Nabolak Atletik Club (SNAC) adalah salah satu wadah tempat pembinaan bibit-bibit atlet berbakat pada usia muda dan pemula dalam cabang olahraga atletik yang salah satunya nomor lempar cakram. Simamora Nabolak Atletik Club yang dilatih oleh pelatih Benny Hutasoit dan bertempat latihan di Jl. Simamora sitanduk, Desa Doloksaribu, Kecamatan Pagaran. Melalui pengamatan peneliti pada 15 Maret 2019 pada saat atlet lempar cakram berlatih bahwasanya masih menggunakan modelmodel latihan yang lama dan sudah sering dilakukan oleh atlet lempar cakram. Peneliti melakukan wawancara terhadap atlet bahwa mereka mengatakan bahwa mereka melakukan latihan berdasarkan arahan dari pelatih dengan bentuk latihan yang dilakukan terarah pada latihan fisik dan tehnik.

Peneliti juga melakukan wawancara kepada pelatih yaitu mengatakan bahwa disetiap latihan, atlet berlatih dari persiapan umum dengan pembentukan pondasi awal untuk membangun dasar-dasar kondisi fisik seperti daya tahan, kekuatan, kecepatan, dan kelentukan dan keterampilan dasar guna untuk menghadapi latihan yang lebih berat dan lebih spesifik pada latihan berikutnya. kemudian pada persiapan khusus latihan yang diberikan kepada atlet mengarah pada latihan yang lebih spesifik pada cabang dari masing-masing atlet dan perbaikan kondisi fisik serta keterampilan atlet.

Pelatih juga menyampaikan bahwa latihan yang diberikan kepada atlet dari persiapan umum seperti latihan beban, push 
up, dan lainnya kemudian pada persiapan khusus dengan latihan yang sama dan hanya meningkatkan beban latihan khususnya otot lengan sebagai anggota tubuh yang paling berperan pada saat melempar, kemudian pada saat melakukan tehnik lemparan hanya menggunakan model simulasi seperti pada pertandingan sesungguhnya.

Peneliti melanjutkan pengamatan di SMA HKBP 2 Tarutung Atletik Club pada 20 Maret 2019, juga salah satu club atletik yang membina bibit-bibit atlet atletik pada usia muda dan pemula. SMA HKBP 2 Tarutung Atletik Club bertempat latihan di Jl. Jend. Ahmad Yani No.20 Kelurahan Hutatoruan X Tarutung, yang dilatih oleh pelatih yaitu Freddy Doloksaribu. Melalui hasil pengamatan peneliti bahwa pada saat latihan, bentuk-bentuk latihan yang diberikan pelatih kepada atlet masih menggunakan latihan yang monoton atau mengarah pada latihan pasif. Peneliti mengamati bahwa latihan yang diberikan hanya fokus pada latihan beban untuk pembentukan otot lengan. Sementara pada latihan tehnik, dilakukan simulasi atau seperti pada saat bertanding dengan menghitung jarak lempar dari atlet

Pernyataan pelatih dari hasil wawancara bahwa pemberian beban latihan pada atlet di fokuskan pada pembentukan kondisi fisik dan tehnik, karena pada lempar cakram bagian yang sangat berperan aktif adalah bagian lengan. Pelatih juga menyampaikan bahwa latihan pada atlet hanya pemberian beban dengan volume dan intensitas yang meningkat seperti latihan otot lengan dengan menggunakan push up, pull up, dumblee, dan lain-lain. Pelatih juga menyampaikan bahwa masih minimnya peralatan latihan beban seperti alat fitnes pada tempat latihan atau didaerah tersebut.

Kemudian peneliti melanjutkan pengamatan pada 22 Maret 2019 salah satu club atletik yang juga membina bibit-bibit atlet lempar cakram pemula. SANMAR ATLETIK CLUB merupakan salah satu club atletik yang bertempat di Jl. Mayjen. D. I. Panjaitan, Kecamatan Tarutung yang dilatih oleh pelatih Dedy Sibarani. Peneliti juga mengamati pada sesi latihan tersebut bentuk latihan juga hanya mengarah pada pembentukan kondisi fisik dasar dan tehnik dasar atlet dengan model latihan yang sering dilakukan menggunakan beban.

Dari hasil wawancara dengan pelatih bahwa pelatih mengatakan bahwa latihan yang diberikan kepada atlet adalah pembentukan kondisi fisik dengan memberikan penambahan beban sesuai target latihan, pelatih hanya menggunakan bentuk- 
bentuk latihan yang sudah ada dalam bukubuku panduan atau internet.

Dari pengamatan peneliti pada ketiga klub atletik tersebut maka yang memperkuat peneliti melakukan penelitian ini didukung dari hasil analisis kebutuhan atlet yang telah dilakukan dengan pengisian angket terhadap 15 orang atlet lempar cakram dari 3 (tiga) club atletik yang masih aktif berlatih, sehingga diperoleh hasil $100 \%$ mengatakan bahwa mereka seorang atlet pemula, $100 \%$ mengatakan bahwa mereka adalah atlet pemula pada nomor lempar cakram, $80 \%$ atlet mengatakan bahwa mereka selalu mengikuti jadwal latihan, 93\% atlet mengatakan bahwa mereka merasa bosan terhadap variasi latihan yang selama ini, 100\% atlet mengatakan bahwa mereka membutuhkan variasi latihan yang baru, 100\% mengatakan bahwa atlet akan lebih giat dalam latihan dengan variasi yang baru, 100\% atlet mengatakan bahwa mereka membutuhkan bentuk latihan lempar cakram yang baru, dan $100 \%$ atlet mengatakan bahwa dengan adanya variasi latihan yang baru, mereka ingin menguasai tehnik lempar cakram.

Berdasarkan hasil pengamatan, wawancara dengan pelatih serta hasil analisis kebutuhan atlet yang dilakukan peneliti, peneliti menyimpulkan bahwa masyarakat atletik secara khusus pada lempar cakram sangat membutuhkan variasi latihan yang baru, yang diharapkan supaya adanya wawasan dan bentuk- bentuk latihan yang baru untuk meningkatkan ketercapaian target dan prestasi.

Dari pendapat yang dikemukakan diatas akan dapat memperkuat peneliti untuk mengambil kesimpulan bahwa perlunya variasi-variasi latihan dalam meningkatkan kemampuan dan semangat atlet serta menambah wawasan bagi pelatih. Untuk menciptakan variasi tersebut perlu dilakukan kajian penelitian yang berjudul: Pengembangan Variasi Latihan pada Atlet Lempar Cakram Pemula.

\section{METODE PENELITIAN}

Sasaran penelitian atau pengguna dalam penelitian pengembangan variasi latihan pada atlet lempar cakram pemula adalah seluruh masyarakat atletik dalam nomor lempar cakram yang masih pemula. Untuk para pelatih dan pembina cabang olahraga atletik dalam nomor lempar, diharapkan menggunakan variasi latihan lempar cakram ini dalam sesi latihan dengan tujuan dan harapan mampu mempertinggi prestasi dan mencapai target atletnya kedepan. Untuk para atlet, menjadikan variasi latihan lempar cakram ini sebagai 
acuan untuk mengambangkan kemampuan yang dimilikinya dalam nomor lempar cakram.

Tempat dan waktu penelitian dilaksanakan di 4 club atletik yang dilakukan di masing-masing tempat latihan club berlatih, waktu pelaksaan penelitian ini dilaksanakan pada bulan Maret sampai Agustus 2020.

Pada uji kelompok kecil melibatkan objek sebanyak 15 orang. Dalam uji coba kelompok kecil ini melibatkan atlet, SNAC (Simamora Nabolak atletik club), SMA HKBP 2 ATLETIK CLUB, dan SANMAR ATLETIK CLUB.

Pada uji coba kelompok besar penelitian ini, peneliti melibatkan 4 club atletik dalam nomor lempar cakram, dengan sampel sebanyak 21 orang. Dalam ujicoba kelompok besar ini peneliti juga melibatkan atlet SNAC (Simamora Nabolak atletik club), SMA HKBP 2 ATLETIK CLUB, SANMAR ATLETIK CLUB, dan SIBORONGBORONG ATLETIK CLUB GENERATION yang masih aktif berlatih.

Metode yang digunakan pada penelitian ini adalah penelitian pengembangan yang mencakup mengembangkan produk, menguji keefektifan produk tersebut untuk mencapai tujuan yang diingankan. Hasil akhir dari penelitian dan pengembangan ini adalah bentuk variasi latihan pada atlet lempar cakram pemula yang baru dan dilengkapi dengan spesifikasi produknya, sehingga dapat digunakan dalam membuat program variasi latihan lempar cakram dan atlet dapat lebih bersungguh-sungguh dan lebih aktif dan efisien dalam berlatih.

Metode penelitian dan pengembangan adalah metode penelitian yang digunakan untuk menghasilkan produk tertentu, dan menguji keefektifan produk tersebut. Penelitian dan pengembangan merupakan penelitian yang bertujuan untuk menghasilkan produk yang berupa variasi latihan pada atlet lempar cakram pemula.

Hasil akhir dari kegiatan penelitian dan pengembangan ini adalah variasi latihan lempar cakram pada olahraga atletik nomor lempar cakram, dengan hasil akhir dari penelitian pengembangan ini akan menghasilkan desain bentuk variasi latihan lempar cakram yang baru dilengkapi dengan spesifikasi produknya, melalui pembuatan buku tentang variasi latihan lempar cakram sehingga dapat digunakan sebagai acuan dalam membuat program latihan. Produk ini sangat cocok untuk atlet pemula karena variasi yang dikembangkan masih bersifat dasar. 


\section{HASIL DAN PEMBAHASAN}

Dalam olahraga prestasi pada nomor lempar cakram, tentunya harus memiliki tehnik yang sempurna dan didukung dengan fisik yang prima. Berbagai bentuk latihan yang dilakukan untuk meningkatkan tehnik dan fisik telah diberikan oleh para pelatih terhadap atlet, tetapi terkadang dengan bentuk latihan yang monoton atau yang sudah sering dilakukan secara berulangulang dalam setiap sesi latihan, sering sekali atlet merasa jenuh dan bosan dalam mengikuti sesi latihan.

Adapun desain produk awal model variasi latihan pada atlet lempar cakram pemula yaitu (1) Latihan Pivot Drill with Cone (2) Latihan Pivot drill with two step (3) Latihan Two-Way throw with one line (4) Lempar Menggunakan Peluru dari Atas Kepala (5) Lempar Menggunakan Tongkat (6) Latihan Lemparan dengan Pantulan Bola (7) Melempar Kantong Pasir Berpasangan (8) Melempar dengan Kantong Pasir Posisi Terlentang (9) Latihan Throw A Tire Over Head (10) Latihan Round the Waist with A Stick (11) Latihan Throw the Bullet in the Lunges Position (12) Latihan Lemparan dengan melewati tali melintang (13) Latihan Lempar dengan Menggunakan Sasaran Bertingkat (14) Latihan Lempar Menggunakan Peluru dari Arah Samping
(15) Latihan Lemparan dengan 1 (satu) Area Sasaran (16) Latihan Lempar Membelakangi Sektor (17) Latihan Variasi lemparan Menyilang (18) Latihan Kombinasi Lemparan Pola Melingkar (19) Latihan Pinggang dengan Alat Bantu Ban (20) Latihan Power Menggunakan Tongkat.

Pengujian pertama dilakukan setelah desain awal ataupun rancangan model latihan lempar cakram untuk pemula diamati, dikoreksi dan dinyatakan layak untuk diujicobakan oleh para ahli. Pengujian pertama terhadap model latihan lempar cakram pada atlet pemula oleh ahli yang terdiri dari 2 orang yaitu 1 orang ahli pelatih dan 1 orang ahli akademisi olahraga. Adapun kompetensi dari ahli tersebut telah diakui dimana pelatih telah memiliki sertifikat pelatih minimal $\mathrm{C}$ dan akademisi telah memiliki pendidikan S1/S2. Hasil evaluasi yang dilakukan ahli mengacu terhadap indikator yang telah disusun sebelumnya dimana menjadi acuan untuk menguji apakah model tersebut layak digunakan atau tidak. Hasil Pengujian Tahap Dua (Uji Kelompok Kecil) Dari hasil uji kelompok kecil dilakukan stelah pakar mengevaluasi produk yang telah dibuat oleh peneliti.

Uji kelompok kecil dlakukan terhadap atlet lempar cakram pemula yang berasal dari tempat latihan Simamora 
Nabolak Atletik Club, SanMar Atletik Club, dan SMA HKBP 2 Tarutung Atletik Club dengan jumlah 15 orang atlet.

Dari hasil uji kelompok kecil pada atlet dimana setelah melakukan setiap model latihan lempar cakram, atlet diberikan angket untuk diisi sesuai pemahaman atlet sendiri. Dari hasil uji coba kelompok kecil terhadap 15 orang atlet lempar cakram pemula disimpulkan bahwa variasi latihan pada atlet lempar cakram pemula dengan jumlah 20 variasi sudah memenuhi kriteria untuk dilanjutkan dalam uji kelompok kecil karena persentase setiap model antara $67 \%$ - 97\%. Dapat disimpulkan bahwa 20 model latihan tersebut mudah dilakukan dan dilaksanakan sehingga dapat meningkatkan kemampuan lempar cakram serta memiliki unsur yang menyenangkan dan menarik untuk dilakukan atau latihan tidak membosankan.

Hasil Pengujian Tahap Ketiga ( Kelompok Besar )

Setelah dilakukan uji coba kelompok kecil maka dilakukan uji kelompok besar terhadap atlet lempar cakram pemula yang berasal dari tempat latihan Simamora Nabolak Atletik Club, SANMAR Atletik Club, SMA HKBP 2 Tarutung Atletik Club, dan SIBORONGBORONG Athletic Club Generation dengan jumlah 21 orang atlet. Dari hasil uji kelompok kecil pada atlet dimana setelah melakukan setiap model latihan lempar cakram, atlet diberikan angket untuk diisi sesuai pemahaman atlet sendiri.

Dari hasil uji coba kelompok kecil terhadap 21 orang atlet lempar cakram pemula disimpulkan bahwa variasi latihan pada atlet lempar cakram pemula dengan jumlah 20 variasi sudah memenuhi kriteria untuk dilanjutkan dalam uji kelompok besar karena persentase setiap model antara $73 \%$ 92\%. Dapat disimpulkan bahwa 20 model latihan tersebut mudah dilakukan dan dilaksanakan sehingga dapat meningkatkan kemampuan lempar cakram serta memiliki unsur yang menyenangkan dan menarik untuk dilakukan atau latihan tidak membosankan.

Proses penyempurnaan produk dilakukan melalui beberapa tahapan yaitu dimulai dari pembuatan draf awal setelah peneliti membuat draf awal lalu peneliti berkonsultasi kepada beberapa pelatih lempar cakram, berikutnya dilakukan evaluasi dari ahli kemudian peneliti merevisi produk tersebut sehingga sudah siap untuk diuji cobakan pada tahap 1 uji coba kelompok kecil yang diikutsertakan 15 orang atlet. pada pelaksanaan uji coba kelompok kecil peneliti memperoleh data dari pernyataan dan saran ahli, pernyataan yang diberikan kepada ahli serta proses revisi menghasilkan 
penyempurnaan produk variasi latihan lempar cakram dalam latihan lempar cakram layak untuk dilanjutkan. Setelah dilakukan uji coba kelompok kecil maka dilakukan penilaian dari setiap ahli olahraga,ahli lempar cakram,dan ahli pelatih lempar cakram, maka setelah selesai diperiksa oleh setiap ahli maka dapat disimpulkan bahwa produk ini sudah layak untuk dimasukkan dalam program latihan dengan harapan dapat meningkatkan kemampuan dalam melakukan lempar cakram pada atlet pemula dengan baik dan sempurna.

Model menjadi sebuah standart atau contoh yang digunakan dalam membuat sesuatu. Model dapat diartikan sebagai variasi atau contoh suatu hal yang akan dihasilkan (Zhang, 2021). Model juga dapat diartikan sebagai acuan yang menjadi dasar atau rujukan dari hal tertentu. Model dapar berupa gambar, rumusan matematis, prototipe, market dan sebagainya. Model didesain untuk mewakili realitas sesungguhnya, walaupun model itu sendiri bukanlah realitas dari dunia yang sebenarnya, sehingga model latihan dapat diartikan sebagai kerangka konseptual yang mendeskripsikan dan melukiskan prosedur yang sistematik dalam mengorganisasikan pengalaman dalam berlatih untuk mencapai tujuan tertentu dan berfungsi sebagai pedoman perencanaan bagi pelatih, fasilitator dan tutor dalam melaksanakan aktivitas dari sebuah latihan. Model menjadi sangat bermanfaat untuk mencapai tujuan yang diharapkan. bermanfaat untuk mencapai tujuan yang diharapkan dengan mengambangkan variasi latihan yang menunjang kemampuan atlet pemula dalam melakukan lempar cakram.

Variasi latihan lempar cakram pada atlet pemula harus dibuat bermanfaat, sesuai dengan tujuan latihan dan prinsip latihan, gerakan dilakukan efektif dan efisien, gerakan yang menyenangkan sesuai dengan gerakan benar sesuai dengan prinsip latihan. Dengan mengikuti ketentuan tersebut maka variasi latihan tersebut berguna untuk digunakan dalam meningkatkan kemampuan lempar pada atlet lempar cakram terkhusus pemula.

Variasi latihan yang dikembangkan tentu saja memiliki keunggulan dan kelemahan dari variasi latihan yang sudah ada sebelumnya (Campanelli \& Parreiras, 2015). Ini dapat memacu peneliti selanjutnya untuk membuat variasi latihan yang lebih baik lagi. Adapun keunggulan variasi latihan pada atlet lempar cakram pemula ini adalah latihan yang dibuat mampu mengembangkan keterampilan dasar pada atlet yang masih baru belajar atau mengikuti latihan lempar 
cakram karena gerakan yang dibuat sesuai dengan gerakan-gerakan dasar lempar cakram.

Kelemahan dari produk ini adalah peralatan latihan harus lengkap dan sesuai dengan ketentuan berat dan jarak yang ditentukan. Hal ini juga akan berpengaruh kepada hasil latihan yang akan dicapai sehingga menjadi perhatian serius bagi pembina/pelatih lempar cakram. Selain itu, karena variasi latihan ini terarah pada atlet lempar cakram pemula, maka pelatih harus memperhatikan gerakan yang dilakukan oleh atlet supaya tidak berdampak ke hal yang negative seperti cedera.

\section{KESIMPULAN}

Berdasarkan hasil dari uji pakar, uji coba lapangan dan hasil pembahasan peneliti, maka dapat disimpulkan bahwa Variasi latihan pada atlet lempar cakram pemula bermanfaat aman dilakukan, gerakan yang dibuat pada setiap model latihan efisien dan efektif. Dengan 20 Model latihan yang sederhana, mudah dilakukan dan dilaksanakan serta memiliki unsur yang menyenangkan dan menarik untuk dilakukan atau latihan tidak membosankan. Dengan pengembangan variasi latihan pada atlet lempar cakram pemula dapat meningkatkan kemampuan lempar cakram bagi atlet pemula.

\section{DAFTAR PUSTAKA}

Alfiansyah, A., Karo, P., Usman, K., Sari, L. P., Dewi, R., Simangunsong, B. A., \& Medan, U. N. (2020). Hasil Pembentukan Karakter Siswa pada Sekolah Full Day School. 2.

Campanelli, A. S., \& Parreiras, F. S. (2015). Agile methods tailoring - A systematic literature review. Journal of Systems and Software, 110, 85-100. https://doi.org/10.1016/j.jss.2015.08.03 5

Fatmala, L., Yusmansyah, \& Ardianto, redi eka. (2018). Hubungan Antara Kepercayaan Diri Dengan Prestasi Belajar Siswa kelas VIII. Jurnal Psikologi Tabularasa, 3(1), 1-15.

Nugroho, R. A., Yuliandra, R., Gumantan, A., \& Mahfud, I. (2021). Pengaruh Latihan Leg Press dan Squat Thrust Terhadap Peningkatan Power Tungkai Atlet Bola Voli. Jendela Olahraga, 6(2), 40-49. https://doi.org/10.26877/jo.v6i2.7391

Sinulingga, A., Alfiansyah, A., Karo-Karo, P., \& Hardinoto, N. (2020). Differences in Character of Competitive Sports Athletes (Comparative Study: Individual Sports and Team Sports) (Vol. 23). https://nasional.kompas.com/read/2009/ 04/25/16460314/seto.pola.pe

Zhang, L. (2021). The Cultivation Path of Sports Spirit in Colleges and Universities Physical Education. ACM International Conference Proceeding Series, 282-285. https://doi.org/10.1145/3452446.34525 22 